\title{
The Role of $\gamma \delta$ T Cells as a Line of Defense in Viral Infections after Allogeneic Stem Cell Transplantation: Opportunities and Challenges
}

\author{
Anke Janssen ${ }^{1,2}$, Eline van Diest ${ }^{2}$, Anna Vyborova ${ }^{2}$, Lenneke Schrier ${ }^{2,3}$, Anke Bruns ${ }^{4}$, Zsolt Sebestyen ${ }^{2}$, \\ Trudy Straetemans ${ }^{1,2}$, Moniek de Witte ${ }^{1}$ and Jürgen Kuball 1,2,*D \\ 1 Department of Hematology, University Medical Center Utrecht, 3584 CX Utrecht, The Netherlands; \\ a.janssen-7@umcutrecht.nl (A.J.); G.C.M.Straetemans@umcutrecht.nl (T.S.); \\ M.A.deWitte-7@umcutrecht.nl (M.d.W.) \\ 2 Center for Translational Immunology, University Medical Center Utrecht, 3584 CX Utrecht, The Netherlands; \\ E.vanDiest@umcutrecht.nl (E.v.D.); A.Vyborova-2@umcutrecht.nl (A.V.); L.Schrier-3@umcutrecht.nl (L.S.); \\ Z.Sebestyen@umcutrecht.nl (Z.S.) \\ 3 Princess Maxima Center for Pediatric Oncology, 3584 CX Utrecht, The Netherlands \\ 4 Department of Infectious Diseases, University Medical Center Utrecht, 3584 CX Utrecht, The Netherlands; \\ A.H.W.Bruns@umcutrecht.nl \\ * Correspondence: j.h.e.kuball@umcutrecht.nl; Tel.: +31-(0)88-75-59030
}

check for updates

Citation: Janssen, A.; van Diest, E.; Vyborova, A.; Schrier, L.; Bruns, A.; Sebestyen, Z.; Straetemans, T.; de Witte, M.; Kuball, J. The Role of $\gamma \delta$ T Cells as a Line of Defense in Viral Infections after Allogeneic Stem Cell Transplantation: Opportunities and Challenges. Viruses 2022, 14, 117. https:/ / doi.org/10.3390/v14010117

Academic Editor: Eric Champagne

Received: 26 November 2021

Accepted: 5 January 2022

Published: 10 January 2022

Publisher's Note: MDPI stays neutral with regard to jurisdictional claims in published maps and institutional affiliations.

Copyright: (C) 2022 by the authors. Licensee MDPI, Basel, Switzerland. This article is an open access article distributed under the terms and conditions of the Creative Commons Attribution (CC BY) license (https:// creativecommons.org/licenses/by/ $4.0 /)$.

\begin{abstract}
In the complex interplay between inflammation and graft-versus-host disease (GVHD) after allogeneic stem cell transplantation (allo-HSCT), viral reactivations are often observed and cause substantial morbidity and mortality. As toxicity after allo-HSCT within the context of viral reactivations is mainly driven by $\alpha \beta$ T cells, we describe that by delaying $\alpha \beta$ T cell reconstitution through defined transplantation techniques, we can harvest the full potential of early reconstituting $\gamma \delta \mathrm{T}$ cells to control viral reactivations. We summarize evidence of how the $\gamma \delta \mathrm{T}$ cell repertoire is shaped by CMV and EBV reactivations after allo-HSCT, and their potential role in controlling the most important, but not all, viral reactivations. As most $\gamma \delta$ T cells recognize their targets in an MHC-independent manner, $\gamma \delta$ T cells not only have the potential to control viral reactivations but also to impact the underlying hematological malignancies. We also highlight the recently re-discovered ability to recognize classical HLA-molecules through a $\gamma \delta$ T cell receptor, which also surprisingly do not associate with GVHD. Finally, we discuss the therapeutic potential of $\gamma \delta \mathrm{T}$ cells and their receptors within and outside the context of allo-HSCT, as well as the opportunities and challenges for developers and for payers.
\end{abstract}

Keywords: $\gamma \delta \mathrm{T}$ cells; allogeneic stem cell transplantation; viral infections; CMV; EBV; T cell depletion

\section{Allogeneic Stem Cell Transplantation Platforms and Viral Reactivations}

Allogeneic hematopoietic stem cell transplantation (allo-HSCT) is the only curative treatment for many hematological malignancies and non-malignant diseases in adults and children. In hematological malignancies, durable remission after this form of immunotherapy depends on the desired graft-versus-leukemia effect but it comes at a cost. Treatment related mortality can be as high as 30\% mainly because of graft-versus-host-disease (GVHD) and infectious complications. Many different allo-HSCT platforms are currently used to counterbalance these risks and overall these achieve an improved GVHD-free overall survival (reviewed in [1]). To date, the majority of allo-HSCT platforms are based on the principle of $\mathrm{T}$ cell depletion. T cell depletion techniques include in vivo $\mathrm{T}$ cell depletion through anti-thymocyte globulin (ATG) [2-5], alemtuzumab [6,7], post-transplantation cyclophosphamide [8-10], and ex vivo graft engineering by CD34 ${ }^{\text {pos }}$ cell selection $[11,12]$ or $\alpha \beta$ T cell depletion [13-16] using a recently well-described anti- $\alpha \beta$ T cell receptor (TCR) antibody [17] (Table 1). The main challenge in choosing between platforms is the lack of 
standardized outcome reports. In addition, substantial variations in patient characteristics, as well as in type of disease and remission status, further hamper valid comparison. Comparing the incidence of viral reactivations or infections between different platforms is even more challenging. The viral infections most frequently seen after allo-HSCT are cytomegalovirus (CMV) and Epstein-Barr virus (EBV), herpes virus 6 (HHV-6), BK pyelomavirus (BKV), and adenovirus (ADV) [18]. In addition to the rather scattered reporting on viral reactivations in different studies (Table 1), a lack of reporting on frequency of, e.g., reactivation in relation to patients at risk and the use of different prophylactic and pre-emptive viral detection and treatment strategies hamper proper analyses. Despite the lack of detailed reporting on viral reactivations in most published studies, viral reactivations such as CMV reactivation were historically considered to be a major driver of increased morbidity and mortality [19]. Infections are a driver for inflammation and inflammation in the presence of $\alpha \beta$ T cells is a driver for GVHD [19,20]. Another cause for inflammation is the classical myeloablative chemotherapy given prior to the infusion of stem cells [19-22], though newer reduced toxicity myeloablative regimens, such as Busulfan, given intravenously in combination with drug monitoring reduces such risks $[23,24]$. The use of unrelated donors for allo-HSCT has also been linked to viral reactivations, as these were often used in combination with $\mathrm{T}$ cell depletion strategies. However, as most centers currently also use $\mathrm{T}$ cell depletion with family donors, the observed increase in viral reactivations after the use of grafts from unrelated donors compared to related donors might not appear in future studies. The most important observation to date is that early immune reconstitution is associated with positive clinical outcomes [25-30]. This emphasizes that the true driver of toxicities after allo-HSCT is the amount of inflammation at a certain time point after allo-HSCT within the context of defined immune repertoires at the moment of inflammation [31-33].

Table 1. Studies reporting on type of transplantation and viral reactivations or infections. Adapted and modified from de Witte et al. [1].

\begin{tabular}{|c|c|c|c|c|c|c|c|c|}
\hline Study & Patients & Donor & Intervention & Numbers & CMV & EBV & BK & Adeno \\
\hline \multicolumn{9}{|c|}{ ATG } \\
\hline $\begin{array}{l}\text { Chang } \\
\text { et al. [2] }\end{array}$ & $\begin{array}{l}\text { Adult } \\
\text { hematological } \\
\text { malignancies }\end{array}$ & MRD & ATG-T & 263 & $\begin{array}{l}\text { Day 100: } \\
22.7 \%\end{array}$ & Day 180: 7.8\% & n.a. & n.a. \\
\hline $\begin{array}{l}\text { Walker } \\
\text { et al. [3] }\end{array}$ & $\begin{array}{l}\text { Adult } \\
\text { hematological } \\
\text { malignancies }\end{array}$ & $\begin{array}{l}\text { MUD } \\
\text { MMUD }\end{array}$ & ATG-T & 101 & n.a. & $\begin{array}{l}20 \% \text { DNAemia } \\
\text { requiring } \\
\text { therapy }\end{array}$ & n.a. & n.a. \\
\hline $\begin{array}{l}\text { Finke } \\
\text { et al. [4] }\end{array}$ & $\begin{array}{l}\text { Adult } \\
\text { hematological } \\
\text { malignancies }\end{array}$ & $\begin{array}{l}\text { MRD } \\
\text { MUD }\end{array}$ & ATG-F & 103 & $\begin{array}{c}53.8 \% \\
\text { DNAemia } \\
5.7 \% \text { CMV } \\
\text { disease }\end{array}$ & $5 \%$ PTLD & n.a. & n.a. \\
\hline $\begin{array}{l}\text { Soiffer } \\
\text { et al. [5] }\end{array}$ & $\begin{array}{l}\text { Adult AML, MDS, } \\
\text { and ALL }\end{array}$ & MUD & ATG-F & 126 & $\begin{array}{c}62 \%(\mathrm{R}+) \\
\text { DNAemie }\end{array}$ & $1.6 \%$ PTLD & n.a. & n.a. \\
\hline \multicolumn{9}{|c|}{ Alemtuzumab } \\
\hline $\begin{array}{l}\text { Green } \\
\text { et al. [6] }\end{array}$ & $\begin{array}{c}\text { Adult } \\
\text { hematological } \\
\text { malignancies }\end{array}$ & $\begin{array}{c}\text { Matched } \\
\text { Mismatched }\end{array}$ & Alemtuzumab & 313 & $\begin{array}{l}>80 \%(\mathrm{R}+) \\
\text { DNAemia }\end{array}$ & n.a. & n.a. & n.a. \\
\hline $\begin{array}{l}\text { Carpenter } \\
\text { et al. [7] }\end{array}$ & $\begin{array}{l}\text { Adult } \\
\text { hematological } \\
\text { malignancies }\end{array}$ & $\begin{array}{l}\text { MRD } \\
\text { MMRD } \\
\text { MUD } \\
\text { MMUD }\end{array}$ & Alemtuzumab & 111 & n.a. & $\begin{array}{c}2 \mathrm{Y} \\
40.3 \% \\
\text { DNAemia } \\
1 \% \text { PTLD }\end{array}$ & n.a. & n.a. \\
\hline \multicolumn{9}{|c|}{ PTCy } \\
\hline $\begin{array}{c}\text { Cieri } \\
\text { et al. [8] }\end{array}$ & $\begin{array}{l}\text { Adult high risk } \\
\text { hematological } \\
\text { malignancy }\end{array}$ & Haplo & PTCy & 40 & $\begin{array}{c}63 \% \\
\text { DNAemia } \\
\text { 17\% CMV } \\
\text { disease }\end{array}$ & $\begin{array}{c}\text { 15\% DNAemia } \\
\text { (66\% of these } \\
\text { pts treated). } \\
\text { No PTLD }\end{array}$ & $18 \%$ & n.a. \\
\hline
\end{tabular}


Table 1. Cont.

\begin{tabular}{|c|c|c|c|c|c|c|c|c|}
\hline Study & Patients & Donor & Intervention & Numbers & CMV & EBV & BK & Adeno \\
\hline $\begin{array}{l}\text { Berger } \\
\text { et al. [9] }\end{array}$ & $\begin{array}{c}\text { Pediatric; high risk } \\
\text { hematological } \\
\text { malignancy }\end{array}$ & Haplo & PTCy & 33 & $\begin{array}{c}36 \% \\
\text { DNAemia } \\
\text { No CMV } \\
\text { disease }\end{array}$ & $\begin{array}{l}\text { 3\% DNAemia } \\
\text { No PTLD }\end{array}$ & $17 \%$ & $\begin{array}{c}3 \% \\
\text { DNAemia; } \\
\text { Not } \\
\text { symptomatic }\end{array}$ \\
\hline $\begin{array}{l}\text { Retiere } \\
\text { et al. [10] }\end{array}$ & $\begin{array}{l}\text { Adult } \\
\text { hematological } \\
\text { malignancies }\end{array}$ & $\begin{array}{l}\text { MRD } \\
\text { MUD } \\
\text { MMUD } \\
\text { haplo }\end{array}$ & $\begin{array}{l}\text { PTCy vs. } \\
\text { ATG-T }\end{array}$ & 45 & $\begin{array}{l}\text { DNAemia } \\
\text { PTCY } 27 \% \\
\text { ATG } 40 \%\end{array}$ & $\begin{array}{l}\text { DNAemia } \\
\text { requiring } \\
\text { treatment } \\
\text { PTCY } 0 \% \\
\text { ATG 33\% }\end{array}$ & $\begin{array}{c}\text { PTCY } \\
3 \% \text { ATG } \\
0 \%\end{array}$ & $\begin{array}{l}\text { PTCY 15\% } \\
\text { ATG 20\% }\end{array}$ \\
\hline \multicolumn{9}{|c|}{$\alpha \beta T$ cell depletion } \\
\hline $\begin{array}{l}\text { De Witte } \\
\text { et al. [13] }\end{array}$ & $\begin{array}{l}\text { Adult } \\
\text { hematological } \\
\text { malignancies }\end{array}$ & $\begin{array}{l}\text { MRD } \\
\text { MUD } \\
\text { MMUD }\end{array}$ & $\begin{array}{c}\alpha \beta \mathrm{T} \text { cell } \\
\text { depletion }\end{array}$ & 35 & $\begin{array}{c}\text { 64\% }(\mathrm{R}+) \\
\text { DNAemia } \\
\text { 6\% CMV } \\
\text { disease }\end{array}$ & $44 \%$ & n.a. & n.a. \\
\hline $\begin{array}{l}\text { Laberko } \\
\text { et al. [14] }\end{array}$ & $\begin{array}{c}\text { Pediatric } \\
\text { malignant }+ \\
\text { non-malignant }\end{array}$ & $\begin{array}{l}\text { MUD } \\
\text { haplo }\end{array}$ & $\begin{array}{c}\alpha \beta \mathrm{T} \\
\text { cell/CD19 } \\
\text { depletion }\end{array}$ & 182 & $51 \%$ & $33 \%$ & n.a. & n.a. \\
\hline $\begin{array}{l}\text { Maschan } \\
\text { et al. [15] }\end{array}$ & $\begin{array}{c}\text { Pediatric high-risk } \\
\text { AML }\end{array}$ & $\begin{array}{l}\text { MUD } \\
\text { MMUD } \\
\text { Haplo }\end{array}$ & $\begin{array}{c}\alpha \beta \mathrm{T} \\
\text { cell/CD19 } \\
\text { depletion }\end{array}$ & 33 & $\begin{array}{c}52 \% \\
\text { DNAemia } \\
6 \% \text { CMV } \\
\text { disease }\end{array}$ & $\begin{array}{l}50 \% \text { DNAemia; } \\
6 \% \text { Rituximab }\end{array}$ & n.a. & n.a. \\
\hline $\begin{array}{l}\text { Bertaina } \\
\text { et al. [16] }\end{array}$ & $\begin{array}{c}\text { Pediatric } \\
\text { non-malignant }\end{array}$ & Haplo & $\begin{array}{c}\alpha \beta \mathrm{T} \\
\text { cell/CD19 } \\
\text { depletion }\end{array}$ & 23 & $\begin{array}{c}38 \% \\
\text { DNAemia } \\
\text { CMV/adeno }\end{array}$ & $\begin{array}{l}50 \% \text { DNAemia; } \\
6 \% \text { Rituximab }\end{array}$ & n.a. & $\begin{array}{c}38 \% \\
\text { DNAemia } \\
\text { CMV/adeno }\end{array}$ \\
\hline
\end{tabular}

Abbreviations: Adeno = adenovirus; ALL = acute lymphoblastic leukemia; AML = acute myeloid leukemia ATG = anti-thymocyte globulin; ATG-F = anti-thymocyte globulin-fresenius; ATG-T = anti-thymocyte globulinthymoglobulin; $\mathrm{BK}=\mathrm{BK}$ virus; $\mathrm{CMV}=$ cytomegalovirus; $\mathrm{EBV}=$ Epstein-Barr virus; haplo = haploidentical donor; $\mathrm{MDS}=$ myelodysplastic syndrome; $\mathrm{MMRD}=$ mismatched related donor; $\mathrm{MMUD}=$ mismatched unrelated donor; $\mathrm{MRD}=$ matched related donor; MUD = matched unrelated donor; NA = not available; PTCY = posttransplantation cyclophosphamide; PTLD = post-transplant lymphoproliferative disease; $p t s=p a t i e n t s ; ~ R+=$ cytomegalovirus positive recipient; and $\mathrm{y}=$ year.

\section{A Common Immunological Nominator for All Transplantation Platforms}

Various transplantation platforms differ substantially in immune reconstitution, although lack of harmonization in reporting and time points of the analyses make comparisons between platforms challenging [1]. In general, NK cells and $\gamma \delta \mathrm{T}$ cells recover within the first weeks after $\alpha \beta$ T depleted allo-HSCT [13,34], whereas ATG-based platforms hamper the reconstitution of $\alpha \beta$ T cells [35]. This is evidenced by the clinical observation that GVHD is rather high when T cell depletion is not performed. The rates of GVHD drop substantially after ATG treatment [2-5], though the level of GVHD might heavily depend on the administered dose $[33,35,36]$. Even lower incidences of, in particular, chronic GVHD are seen after post-transplantation cyclophosphamide [8-10] and ex vivo graft engineering through $\alpha \beta$ T cell depletion [13-16]. One common nominator of success for all platforms seems to be the recovery of the numbers of CD4+ $\alpha \beta$ T cells after allo-HSCT, although recovery is slow and can take months or even years [37]. Although slowly repopulating, numbers of CD4+ $\alpha \beta$ T cells early after allo-HSCT have been reported as a major predictor for viral reactivations and improved clinical outcome [25-30,38]. Recovery of innate immune cells, defined as neutrophil, monocyte, and NK cells, have been proposed as a good predictor for CD4 $+\alpha \beta$ T cell reconstitution [29]. NK and $\gamma \delta \mathrm{T}$ cells are part of the first innate immune cells to reconstitute after allo-HSCT [13,39,40], though their clinical impact has not been thoroughly investigated yet.

\section{3. $\gamma \delta$ T Cells, the Frequently Forgotten Child, within the Context of Allo-HSCT}

$\gamma \delta \mathrm{T}$ cell subsets exhibit distinct developmental properties, tissue localizations, and activation modes. Generally, human $\gamma \delta \mathrm{T}$ cells are divided into two major structural subsets according to their TCR $\delta$ chain usage: $V \delta 2^{\text {pos }} \mathrm{T}$ cells and $\mathrm{V} \delta 2^{\text {neg }} \mathrm{T}$ cells. The majority of 
the $\mathrm{V} \delta 2^{\text {neg }} \mathrm{T}$ cells express the $\mathrm{V} \delta 1$ chain and co-express different $\mathrm{V} \gamma$ chains, whereas the majority of $\mathrm{V} \delta 2^{\text {pos }} \mathrm{T}$ cells co-express $\mathrm{V} \gamma 9$. In general, $\mathrm{V} \gamma 9 \mathrm{~V} \delta 2 \mathrm{~T}$ cells are the main subset of $\gamma \delta \mathrm{T}$ cells in the peripheral blood and are able to recognize infections such as tuberculosis and malignant cells [41,42]. The anti-viral capacities of $\gamma \delta \mathrm{T}$ cells have been described for different viruses such as CMV, EBV, influenza, and HCV (hepatitis C virus), and more recently SARS-CoV-2 [43]. $\gamma \delta \mathrm{T}$ cells act as early responders with the upregulation of Tolllike receptors (TLRs) which recognize pathogen-associated molecular patterns (PAMPs), such as viral particles, initiating a cascade which leads to the production of interferons and pro-inflammatory cytokines [44]. $\gamma \delta$ T cells also express NK type receptors, such as natural killer group member 2-D (NKG2D) which are activated in response to stress of, for instance, virally infected cells and mediate the production of both perforins and granzyme B, thereby increasing cytotoxicity [45]. Finally, $\gamma \delta$ T cells can be directly activated by their TCR upon viral infection and produce several cytokines of which IFN- $\gamma$ is the best studied. Activated $\gamma \delta \mathrm{T}$ cells have a direct cytotoxic function by inducing apoptosis of virally infected cells but they also have an indirect effect by recruiting the immune system by producing pro-inflammatory cytokines [43].

Despite increasing interest in $\gamma \delta$ T cells, the vast majority of studies on immunological immune repertoires after allo-HSCT do not include $\gamma \delta$ T cells in their analyses, though $\gamma \delta$ $\mathrm{T}$ cells comprise up to $10 \%$ of the peripheral T cells in healthy individuals [41]. The reasons for not adding $\gamma \delta \mathrm{T}$ cells to immune monitoring panels might be manifold. For example, detection of $\gamma \delta$ T cells is technically difficult, as, e.g., anti-CD3 antibodies can block $\gamma \delta$ TCR staining and an appropriate choice of antibody clones is essential. However, as $\gamma \delta \mathrm{T}$ cells have the potential to control viral infections and tumor cells, efforts should be made to overcome these barriers so that more can be learned about their role within the immune reconstitution after allo-HSCT.

Reconstitution of $\gamma \delta$ T cells and its relation to clinical outcomes after allo-HSCT has not been studied extensively. Results of single-center studies suggest a favorable role of $\gamma \delta \mathrm{T}$ cells after allo-HSCT, where an increased number of $\gamma \delta \mathrm{T}$ cells after allo-HSCT is associated with improved relapse-free survival and overall survival [46-49]. One study, however, showed that increased numbers of CD8pos $\gamma \delta$ T cells in the graft, a minor subset of all $\gamma \delta$ T cells, were associated with an increased cumulative incidence of acute GVHD [50]. This specific subset seems to be more prone to allo-reactivity and thereby GVHD, with the upregulation of activation markers after in vitro mixed lymphocyte reaction (MLR) when compared to CD8 ${ }^{\text {neg }} \gamma \delta \mathrm{T}$ cells [50]. The same study showed that an increase in CD27pos $\gamma \delta$ T cells, which are capable of producing IFN- $\gamma$, in the graft was correlated with less relapse [50]. Despite these scattered reports on $\gamma \delta \mathrm{T}$ cells in relation to clinical outcomes, a recent meta-analysis confirmed favorable outcomes for event-free survival and overall survival in patients with increased numbers of $\gamma \delta \mathrm{T}$ cells after allo-HSCT [51]. Moreover, higher numbers of $\gamma \delta$ T cells were associated with fewer relapses and fewer viral infections [51]. No association with the number of $\gamma \delta$ T cells and the occurrence of GVHD was observed [51]. This is consistent with the observation that transplantation techniques, which heavily depend on NK and $\gamma \delta$ T cells, associate with low incidences of GVHD [1,13].

The underlying molecular mechanism used by $\gamma \delta \mathrm{T}$ cells to control hematological malignancies in the first months after allo-HSCT is based on the ability of $\gamma \delta$ T cells to recognize their targets in a major histocompatibility complex ( $\mathrm{MHC}$ )-independent manner. Therefore, $\gamma \delta$ T cells do not cause substantial GVHD, in contrast to $\alpha \beta$ T cells, while they still exert their effect on tumor cells and virally infected cells [52]. V $\gamma 9 \mathrm{~V} \delta 2 \mathrm{~T}$ cells sense changes in phosphoantigens (pAg) via their TCR. The current working hypothesis is that pAg accumulation within the cell results in changes in BTN2 and BTN3, modulated by RhoB, which can be sensed by the V $\gamma 9 \mathrm{~V} \delta 2$ TCR [53-59]. Ligands for V $\delta 2^{\text {neg }} \gamma \delta \mathrm{T}$ cells, the dominant population in tissues, are less thoroughly described [41,60]. An interesting unexpected feature of $V \delta 2^{\text {neg }} \gamma \delta \mathrm{T}$ cells is that they have been reported to cross-recognize classical HLA molecules, such as HLA-A24, by their $\gamma \delta$ TCR [61]. Surprisingly, for this particular V $\gamma 5 \mathrm{~V} \delta 1 \mathrm{TCR}$, normal cells are not recognized most likely because clustering of the 
HLA-A24 molecule on the cell membrane is important for recognition, which might differ between healthy and tumor cells [61]. The cross-recognition of classical HLA molecules by selected $\gamma \delta$ TCR could be interesting to explore for controlling underlying hematological malignancies across HLA barriers and for genetic engineering strategies [62-64]. This finding is neither an artifact nor a rare event and is supported by findings from more than two decades ago when others had already described HLA A24 reactive $\gamma \delta$ T cells and $\gamma \delta$ TCRs [65]. Additionally, HLA-A2 [66] and B27 [67]-specific $\gamma \delta$ T cells have been described, though no detailed analyses to study cross-reactivity towards healthy tissues has been performed for these TCRs.

\section{CMV Infections Alter the $\gamma \delta$ T Cell Repertoire after Allo-HSCT}

Repertoire studies of the $\gamma \delta$ TCR after allo-HSCT showed that the diversity of the repertoire recovered within the first months after allo-HSCT and remained stable thereafter [40]. The $\gamma \delta$ TCR repertoire after allo-HSCT seems to be mainly based on de novo generation of $\gamma \delta \mathrm{T}$ cells, although also $\gamma \delta \mathrm{TCRs}$ identified in the graft could be found in the patient's new repertoire [40]. Viral reactivation after allo-HSCT, in particular after CMV reactivation, resulted in a skewed $\gamma \delta \mathrm{TCR}$ repertoire with an expansion of specific $\mathrm{V} \delta 2^{\text {neg }}$ $\gamma \delta \mathrm{T}$ cell clones [40,68-70]. These clones usually have a V $\delta 1 \mathrm{TCR}$ but expansions of $\mathrm{V} \delta 3^{\text {pos }} \mathrm{T}$ cells have also been described $[40,69]$. Both $V \delta 1^{\text {pos }}$ and $V 83^{\text {pos }} \mathrm{T}$ cells are more often found in epithelial tissue where viral replication takes places, which explains their increase after CMV infection $[45,70]$. The increase in V $\delta 2^{\text {neg }} \gamma \delta$ T cells after CMV infection was shown in different transplantation settings, such as in T cell replete, umbilical cord, and HLAhaploidentical transplantations [49,69,71-74]. These observations are also supported by $\gamma$ TCR chain (TRG) sequencing analyses, which imply that despite CMV infection reshaping the TRG repertoire, TRG composition is not associated with aGvHD development [75].

The killing capacity of polyclonal $V \delta 2^{\text {neg }} \gamma \delta$ T cells isolated from patients with a CMV reactivation was assessed by different laboratories and in vitro co-culture of those cells with CMV-infected fibroblasts showed specific lysis and interferon- $\gamma$ production, as well as crossreactivity against different tumors $[69,74,76-78]$. This provides a potential explanation for the paradox that CMV reactivation associates with improved leukemia control [79-81] mainly in T cell-depleted platforms. However, in T cell replete transplantation platforms, CMV seropositivity of the patient and/or donor is frequently associated with an increased non-relapse mortality, even with preemptive treatment programs for CMV after alloHSCT $[82,83]$. This might be caused because, as has been observed, CMV reactivation within the context of $\mathrm{T}$ cell replete transplantation platforms leads to extensive inflammation and GVHD. In line with this, a large database study could not confirm the protective effect of CMV on relapse and even showed an increase in transplant-related mortality in patients with CMV reactivation [84] (for review [85]). This is in contrast to data from T cell-depleted allo-HSCT and CMV reactivations, which are more in line with the first reports on the $\gamma \delta$ $\mathrm{T}$ cell response upon CMV infection in kidney transplanted patients, a clinical scenario where major inflammation is missing [86]. In this cohort, the expansion of $\gamma \delta \mathrm{T}$ cells was driven by $\mathrm{V} \delta 2^{\text {neg }} \gamma \delta \mathrm{T}$ cells and the oligoclonality of the $\gamma \delta \mathrm{T}$ cell receptor repertoire in the CMV-infected patients is suggestive for in vivo antigen-driven selection of V $\delta 2^{\text {neg }} \gamma \delta \mathrm{T}$ cells [87]. The expansion of $\gamma \delta$ T cells was associated with the resolution of CMV infection, which points to a protective role of $\gamma \delta \mathrm{T}$ cells in CMV [88]. In addition to the $\mathrm{V} \delta 2^{\text {neg }} \gamma \delta \mathrm{T}$ cells, the recent occurrence of a V $\delta 2$-positive but $V \gamma 9$-negative $\gamma \delta \mathrm{T}$ cell population has been described in CMV infections after kidney transplantation. The expansion of this population is more outspoken in severe cases of CMV disease [89]. Whether such cells also play a role after allo-HSCT needs further investigation.

\section{5. $\gamma \delta \mathrm{T}$ Cells Immune Reconstitution after Allo-HSCT and Interplay with EBV Infections}

EBV reactivations are a common complication of allo-HSCT, though they are less frequently observed than CMV reactivations (Table 1). However, when not controlled, 
post-transplantation lymphoproliferative disease (PTLD) is a rare but feared complication of EBV reactivation, mainly observed after $\mathrm{T}$ cell-depleted transplantations prior to the era of anti-CD20 therapies [90]. Patients with low V $\gamma 9 \mathrm{~V} \delta 2 \mathrm{~T}$ cell numbers after allo-HSCT from HLA-haploidentical donors have been reported to have increased incidences of EBVreactions [91]. Interestingly, for the $\alpha \beta$ T cell-depleted platform, EBV reactivations are quite frequent in the absence of CD19-depletion [13], while adding CD19-depletion substantially reduces EBV reactivations (M. de Witte, J. Kuball, unpublished observations). This finding is, on the one hand, surprising, as studies on the mode of action of the $\mathrm{V} \gamma 9 \mathrm{~V} \delta 2 \mathrm{~T}$ cell receptor were performed in EBV-transformed B cells and allowed us to identify RhoB as a key modulator for the recognition of tumor cells by a $\mathrm{V} \gamma 9 \mathrm{~V} \delta 2 \mathrm{TCR}$ [58], implying that $\gamma \delta \mathrm{T}$ cells can control EBV reactivation. However, recognition of EBV-transformed B cells depended on the additional administration of aminobisphosphonates and was donor-dependent. Additionally, within one donor, the capability to recognize EBV-transformed B cells varies substantially [55]. Others have also shown that aminobisphosphonate pamidronate-expanded human V $\gamma 9 \mathrm{~V} \delta 2 \mathrm{~T}$ cells efficiently kill EBV-transformed autologous lymphoblastoid B cell lines through V V $982 T C R$ and NKG2D receptor triggering, as well as through Fas and TRAIL engagement [92]. Thus, the underlying mechanism of donor dependency is most likely mediated by genetic variations, which allow some patients to control EBV reactivations by $\mathrm{V} \gamma 9 \mathrm{~V} \delta 2 \mathrm{~T}$ cells, while others lack the ability to properly activate this pathway due to single-nucleotide polymorphism (SNPs) [58]. This observation is in line with a report showing that different individuals mount different types of innate immune responses after EBV exposure. While one type of immune response utilizes NK and $\mathrm{V} \gamma 9 \mathrm{~V} \delta 2 \mathrm{~T}$ cells during EBV reactivation, others are only able to expand NK cells [93].

$\mathrm{V} \delta 1^{\text {pos }} \gamma \delta \mathrm{T}$ cells likely also play a role in EBV infection, as the expansion of these cells was seen in primary EBV infection [94]. In the context of allo-HSCT, skewing of the $\gamma \delta \mathrm{T}$ cell receptor repertoire towards oligoclonal V $\delta 1^{\text {pos }} \gamma \delta \mathrm{T}$ cells after EBV reactivation has been reported [68]. In this study, an in vitro expanded V $\delta 1^{\text {pos }} \mathrm{T}$ cell clone showed cytotoxicity against EBV-LCL. EBV-infected cells could also induce in vitro oligoclonal expansions of autologous $\mathrm{V} \delta 1^{\text {pos }} \gamma \delta \mathrm{T}$ cells from EBV-seropositive individuals. Furthermore, after cord blood transplantation in a patient with a prolonged EBV reactivation, $\mathrm{V} \delta 1^{\text {pos }} \gamma \delta \mathrm{T}$ cells expanded, which showed lytic activity against EBV-LCL [95]. However, other studies did not report $\mathrm{V} \delta 1^{\text {pos }}$-positive $\gamma \delta \mathrm{T}$ cell expansion after EBV reactivation [69].

\section{The Role of $\gamma \delta$ T Cells in Other Viruses after Allo-HSCT: An Unexplored Field}

While human $\gamma \delta \mathrm{T}$ cell responses and their anti-viral capacities after allo-HSCT are best studied in herpes viruses such as CMV or EBV, studies regarding the role of $\gamma \delta \mathrm{T}$ cells in other herpes viruses such as HHV-6 and varicella-zoster virus (VZV), or non-herpes viruses such as ADV and BKV, are lacking. Data on $\gamma \delta \mathrm{T}$ cell responses to infections with other herpes viruses, although rare after allo-HSCT, is available only outside the context of allo-HSCT, but is informative on the role of $\gamma \delta \mathrm{T}$ cells in viral infections. For example, in kidney-transplanted patients, no increase in $\gamma \delta \mathrm{T}$ cells was observed after infection with other herpes viruses such as varicella zoster virus (VZV), herpes simplex virus (HSV), or EBV [86]. Reports on human herpes virus 8 (HHV-8) showed that upon infection, an increase in $\mathrm{V} \delta 1^{\text {pos }} \gamma \delta \mathrm{T}$ cells is observed [96]. Additionally, $\mathrm{V} \delta 1^{\text {pos }} \gamma \delta \mathrm{T}$ cell activation was observed when the PBMCs of infected patients with HHV-8 were stimulated with viral particles of HHV-8. In addition, $\mathrm{V} \delta 1^{\text {pos }} \gamma \delta \mathrm{T}$ cells could decrease the release of viral particles in HHV-8-infected cell lines. Interestingly, the $\gamma \delta \mathrm{T}$ cell response in herpes simplex virus (HSV) was reported to consist mainly of $\mathrm{V} \gamma 9 \mathrm{~V} \delta 2 \mathrm{~T}$ cells $[97,98]$. Based on our current knowledge, these $\mathrm{V} \gamma 9 \mathrm{~V} \delta 2 \mathrm{~T}$ cells probably did not recognize a specific viral antigen because in vitro experiments showed lysis by these $\mathrm{V} \gamma 9 \mathrm{~V} \delta 2 \mathrm{~T}$ cells of not only HSV-infected cells but also of cells infected with other viruses. $\gamma \delta \mathrm{T}$ cell responses in non-herpes viruses are, among others, studied in HIV, influenza, and recently SARS-CoV-2. In primary HIV infection, the depletion and loss of activation potential of $\mathrm{V} \delta 2^{\text {pos }} \gamma \delta \mathrm{T}$ cells was observed together with an increase in $\mathrm{V} \delta 1^{\text {pos }} \gamma \delta$ T cells. In elite controllers, the V $\delta 1^{\text {pos }} \gamma \delta \mathrm{T}$ cell 
expansion was even more pronounced, suggesting that they play a role in controlling the virus [99]. More recently, the severe depletion of $V \delta 2^{p o s} \gamma \delta \mathrm{T}$ cells together with an increased differentiation and activation profile has been described in severe SARS-CoV-2 infection [100,101]. Activated V $\gamma 9 \mathrm{~V} \delta 2$ T cells were capable of killing influenza-infected lung alveolar epithelial cells in vitro, showing the potential contribution to viral clearance at the actual site of the infection [102]. Taken together, viral infections consistently alter the composition and phenotype of the $\gamma \delta$ T cell compartment, and the anti-viral capacity of $\gamma \delta \mathrm{T}$ cells has been demonstrated in vitro. However, the exact role of $\gamma \delta \mathrm{T}$ cells in viral disease and their contribution to viral clearance in relation to other immune cells remain to be elucidated.

\section{Unmodified $\gamma \delta$ T Cells for Treatment of Viruses after Allo-SCT}

To improve immune reconstitution and enhance the graft-versus-leukemia effect after allo-HSCT, different variants of donor lymphocyte infusion (DLI) have been studied. DLIs are administered as a prophylactic, pre-emptive, or therapeutic treatment; consist of either unmanipulated or manipulated cell products; and have additional value within the context of T cell-depleted allo-HSCT [1]. Consensus regarding the timing and dosing of DLI is lacking and currently primarily depend on the allo-HSCT platform (reviewed in [31]). For pragmatic reasons, DLIs are not purified and are thus mainly comprised of $\alpha \beta$ T cells, however they also harbor many other immune subsets, including NK and $\gamma \delta$ T cells. However, when analyzing the mode of action of unmanipulated DLI, the main focus is usually on $\alpha \beta$ T cells. Additionally, only a limited number of reports are available on either the modulation of $\gamma \delta \mathrm{T}$ cells by drugs or on the infusion of isolated $\gamma \delta \mathrm{T}$ cells. Infusion of predominantly NK and $\gamma \delta \mathrm{T}$ cells with $\alpha \beta \mathrm{T}$ cell-depleted grafts during allo-HSCT and observed incidences of CMV and EBV reactivation when compared to T-cell replete allo-HSCT imply a strong ability of $\gamma \delta$ T cells to control CMV reactivation. However, the capacity to control EBV reactivations seems to be limited in the absence of phosphoantigen-stimulating agents (Table 1). Aminobisphosphonates, such as pamidronate or zoledronic acid, are phosphoantigen-stimulating drugs and have been used extensively, sometimes in combination with interleukin-2 (IL-2) to stimulate V $\gamma 9 \mathrm{~V} \delta 2 \mathrm{~T}$ cells in vitro. Aminobisphosphonates have few side effects and could, in theory, be used as a therapeutic tool after allo-HSCT to enhance the potential of $\mathrm{V} \gamma 9 \mathrm{~V} \delta 2 \mathrm{~T}$ cells to attack the underlying hematological malignancy, as well as EBV reactivations. In vivo or in vitro stimulation of autologous $\gamma \delta$ T cells with aminobisphosphonates and/or IL-2 has been mainly studied in trials for cancer treatment, although no severe toxicity was reported and there was a lack clinical efficacy [41,42]. A study which explored in vivo treatment with zolendronic acid in pediatric patients treated with $\alpha \beta$ T cell-depleted allo-HSCT reported no severe toxicities but patient numbers were too small to assess the impact on viral infections or

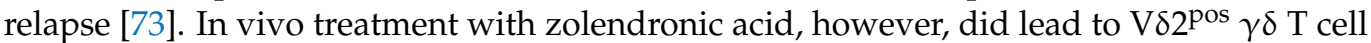
differentiation with increased cytotoxicity against leukemic blasts in vitro. Interestingly, the percentage of the $\mathrm{V} \delta 1^{\text {pos }} \gamma \delta \mathrm{T}$ cells of patients treated with zolendric acid was increased and also these $\mathrm{V} \delta 1^{\text {pos }} \gamma \delta \mathrm{T}$ cells showed increased cytotoxicity against leukemic blasts. There is no explanation for this unexpected finding but the authors speculate about the role of the bloom syndrome protein (BLM), which was found to be upregulated in $\gamma \delta \mathrm{T}$ cells treated with zolendronic acid [73]. BLM is involved in the development and maintenance of $\alpha \beta$ T cells [103]. These findings exemplify the gaps in knowledge about the complex interplay between $\mathrm{V} \delta 2$ and both $\mathrm{V} \delta 1 \gamma \delta \mathrm{T}$ cells and $\alpha \beta$ T cells.

\section{Picking and Engineering Winners from $\gamma \delta$ T Cells and Their Receptors for Future Anti-Viral Therapies}

The most recent insights further stress the inter and intra-individual diversity of $\mathrm{V} \gamma 9 \mathrm{~V} \delta 2 \mathrm{~T}$ cells, as very detailed clonal analyses imply that many high frequency $\mathrm{V} \gamma 9 \mathrm{~V} \delta 2 \mathrm{~T}$ cell clones are poorly active against EBV-transformed or solid cancers [55]. Surprisingly, the NKG2A-positive subpopulation of $\mathrm{V} \gamma 9 \mathrm{~V} \delta 2 \mathrm{~T}$ cells is a source for more active clones, 
though optimal responses are observed with additional blocking through anti-HLA-Einterfering agents [104]. These data would suggest that the selection of NKG2A-positive subpopulations of $\mathrm{V} \delta 2^{\text {pos }} \mathrm{T}$ cells before infusion or HLA-E-blocking antibodies should be explored for future $\mathrm{V} \gamma 9 \mathrm{~V} \delta 2 \mathrm{~T}$ cell therapies. To harvest the potential of $\mathrm{V} \delta 2^{\text {neg }} \gamma \delta \mathrm{T}$ cells, the expansion of polyclonal V $\delta 1^{\text {pos }} \gamma \delta \mathrm{T}$ cells, the so-called Delta One T cells (DOT), has been proposed and is currently being tested in clinical trials $[105,106]$. Though such strategies are mainly being explored within the context of cancer treatment (for review [41,42]), they are also an interesting treatment option for viral reactivations. $\gamma \delta \mathrm{T}$ cell-based therapies would allow for overcoming limitations of, e.g., HLA-restricted off-the-shelf virus-specific T cell banks [107]. Additionally, using $\gamma \delta$ T cells as carriers for virus-specific $\alpha \beta T C R$ was explored with CMV and ADV-specific $\alpha \beta T C R[108,109]$. $\gamma \delta$ T cells engineered with a chimeric antigen receptor (CAR) are currently under investigation but again in the context of cancer treatment [110]. Though the use of $\gamma \delta \mathrm{T}$ cells as a third-party carrier would avoid the risks of GVHD, the limited in vitro proliferation capacity of $\gamma \delta$ T cells could hamper such a strategy.

Lastly, using highly active compounds to target infected cells could rely on engineering strategies. These can include either extracting tumor and virus reactive receptors, e.g., of $\mathrm{V} \gamma 9 \mathrm{~V} \delta 2 \mathrm{~T}$ cell receptors for the generation of $\mathrm{T}$ cells engineered with an optimized $\mathrm{V} \gamma 9 \mathrm{~V} \delta 2 \mathrm{~T}$ cell receptor (TEG) $[55,58,64,111-114]$ or of V $\delta 2$-negative $\gamma \delta$ T cell receptors $[60-62,64]$. Such strategies allow for the generation of autologous long-lasting effector cells and overcome the HLA-restriction of engineered virus-specific $\alpha \beta$ T cells. Finally, the so- called V $\gamma 9 \mathrm{~V} \delta 2 \mathrm{~T}$ cell receptors have been used to generate a bispecific format [115], namely the so-called Gamma delta TCR Anti-CD3 Bispecific molecules (GABs), as novel immunotherapeutic compounds which could, e.g., in combination with aminobisphosphonates, allow for rapid off-the-shelf treatment for EBV reactivations or EBV-transformed lymphoma, and would also not depend on HLA-restriction. For an overview of possible $\gamma \delta \mathrm{T}$ cell-mediated anti-viral therapies, see Figure 1.

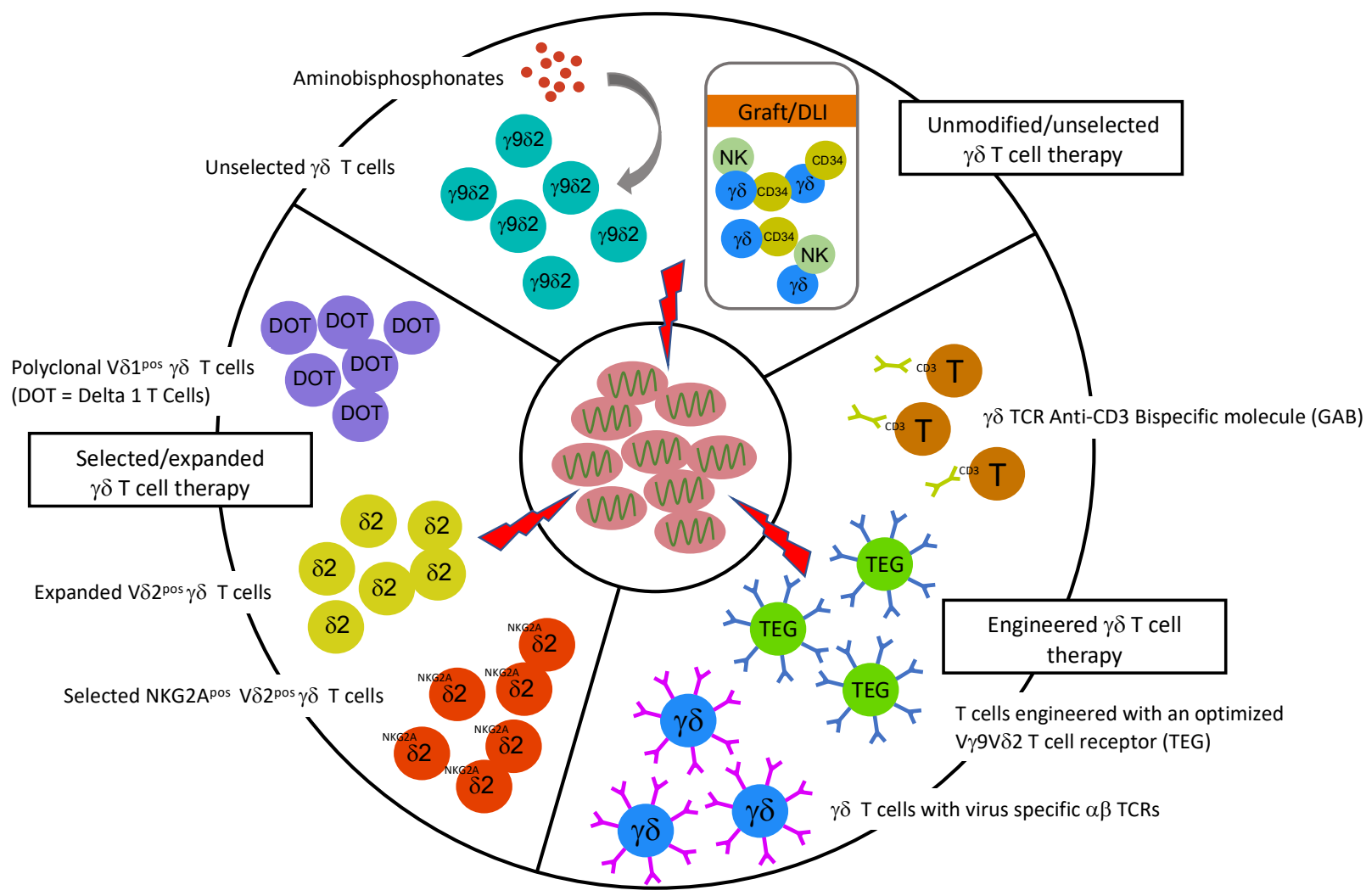

Figure 1. Possible $\gamma \delta$ T cell-mediated therapies in viral infections. 


\section{Conclusion within the Context of Other Anti-Viral Compounds and Re-Imbursement Dilemmas}

To conclude, $\gamma \delta \mathrm{T}$ cells are currently often overlooked in studies regarding immune reconstitution and reports on both $\gamma \delta \mathrm{T}$ cells and viral infections are scarce. However, with their anti-viral capacities, they are believed to be an important line of defense in the inflammatory environment in the first months after allo-HSCT without causing GVHD. These beneficial properties have led to the development of allo-HSCT platforms where $\gamma \delta \mathrm{T}$ cells are an important pillar in the immune reconstitution. Moreover, $\gamma \delta \mathrm{T}$ cells are an interesting candidate for future cellular antiviral therapies after allo-HSCT. However, within the context of allo-HSCT, from a drug development perspective, major attention should also be drawn to other developed antiviral compounds, such as letermovir [116], which has been recently approved and is reimbursed in many countries for preventing CMV reactivation. A major assumption for prevention, as well as for treatment strategies, relies on an immune system which also harbors virus-reactive immune cells. Without these cells, only temporary control of the viral load can be achieved. Therefore, developing additional cellular immune therapies to enrich a fragmented immune repertoire remains a major field of interest. However, as allo-HSCT is already a costly intervention and access to it is not equal for all European citizens [117], additional high-end prices will most likely not be accepted by many payers. To date, overpriced products, in combination with a long production time, have only been accepted for CAR T cells because of their nature as a single intervention for a cure with a big impact $[118,119]$. After two decades of development, production time and pricing are likely the critical factors contributing to the failure of bringing other advanced cellular therapy products (ATMPs) to market, such as HSV-TK (thymidine kinase)-modified T cells [120], which were designed as add-ons to an allo-HSCT. The community that is working to develop such novel interventions should learn from these past failures and find ways to enable timely and affordable access to the market.

Author Contributions: Conceptualization: A.J. and J.K., Writing-original draft preparation: A.J., E.v.D. and J.K., Writing - review and editing: A.V., L.S., A.B., T.S., M.d.W. and Z.S., Supervision: J.K., Funding acquisition: M.d.W. and J.K. All authors have read and agreed to the published version of the manuscript.

Funding: Funding for this study was provided by KWF UU 2015-7553 to M.A.d.W as well as ZonMW 43400003 and VIDI-ZonMW 917.11.337, KWF UU 2010-4669, UU 2013-6426, UU 2014-6790 and UU 2015-7601, UU 2018-11393, UU 2018-11979, UU 2020-12586, and UU 2021-13043 to J.K.

Conflicts of Interest: J.K. reports grants from Gadeta, Novartis, and Miltenyi Biotech; is the inventor on patents dealing with $\gamma \delta \mathrm{T}$ cell-related aspects; as well as is the co-founder and shareholder of Gadeta. S.Z. is an inventor on patents dealing with $\gamma \delta \mathrm{T}$ cell-related aspects.

\section{References}

1. de Witte, M.; Daenen, L.G.M.; van der Wagen, L.; van Rhenen, A.; Raymakers, R.; Westinga, K.; Kuball, J. Allogeneic Stem Cell Transplantation Platforms With Ex Vivo and In Vivo Immune Manipulations: Count and Adjust. Hemasphere 2021, 5, e580. [CrossRef]

2. Chang, Y.J.; Wu, D.P.; Lai, Y.R.; Liu, Q.F.; Sun, Y.Q.; Hu, J.; Hu, Y.; Zhou, J.F.; Li, J.; Wang, S.Q.; et al. Antithymocyte Globulin for Matched Sibling Donor Transplantation in Patients With Hematologic Malignancies: A Multicenter, Open-Label, Randomized Controlled Study. J. Clin. Oncol. Off. J. Am. Soc. Clin. Oncol. 2020, 38, 3367-3376. [CrossRef] [PubMed]

3. Walker, I.; Panzarella, T.; Couban, S.; Couture, F.; Devins, G.; Elemary, M.; Gallagher, G.; Kerr, H.; Kuruvilla, J.; Lee, S.J.; et al. Addition of anti-thymocyte globulin to standard graft-versus-host disease prophylaxis versus standard treatment alone in patients with haematological malignancies undergoing transplantation from unrelated donors: Final analysis of a randomised, open-label, multicentre, phase 3 trial. Lancet Haematol. 2020, 7, e100-e111.

4. $\quad$ Finke, J.; Bethge, W.A.; Schmoor, C.; Ottinger, H.D.; Stelljes, M.; Zander, A.R.; Volin, L.; Ruutu, T.; Heim, D.A.; Schwerdtfeger, R.; et al. Standard graft-versus-host disease prophylaxis with or without anti-T-cell globulin in haematopoietic cell transplantation from matched unrelated donors: A randomised, open-label, multicentre phase 3 trial. Lancet. Oncol. 2009, 10, 855-864. [CrossRef]

5. Soiffer, R.J.; Kim, H.T.; McGuirk, J.; Horwitz, M.E.; Johnston, L.; Patnaik, M.M.; Rybka, W.; Artz, A.; Porter, D.L.; Shea, T.C.; et al. Prospective, Randomized, Double-Blind, Phase III Clinical Trial of Anti-T-Lymphocyte Globulin to Assess Impact on Chronic 
Graft-Versus-Host Disease-Free Survival in Patients Undergoing HLA-Matched Unrelated Myeloablative Hematopoietic Cell Transplantation. J. Clin. Oncol. Off. J. Am. Soc. Clin. Oncol. 2017, 35, 4003-4011. [CrossRef] [PubMed]

6. $\quad$ Green, K.; Pearce, K.; Sellar, R.S.; Jardine, L.; Nicolson, P.L.R.; Nagra, S.; Bigley, V.; Jackson, G.; Dickinson, A.M.; Thomson, K.; et al. Impact of Alemtuzumab Scheduling on Graft-versus-Host Disease after Unrelated Donor Fludarabine and Melphalan Allografts. Biol. Blood Marrow Transplant. J. Am. Soc. Blood Marrow Transplant. 2017, 23, 805-812. [CrossRef]

7. Carpenter, B.; Haque, T.; Dimopoulou, M.; Atkinson, C.; Roughton, M.; Grace, S.; Denovan, S.; Fielding, A.; Kottaridis, P.D.; Griffiths, P.; et al. Incidence and dynamics of Epstein-Barr virus reactivation after alemtuzumab-based conditioning for allogeneic hematopoietic stem-cell transplantation. Transplantation 2010, 90, 564-570. [CrossRef] [PubMed]

8. Cieri, N.; Greco, R.; Crucitti, L.; Morelli, M.; Giglio, F.; Levati, G.; Assanelli, A.; Carrabba, M.G.; Bellio, L.; Milani, R.; et al. Post-transplantation Cyclophosphamide and Sirolimus after Haploidentical Hematopoietic Stem Cell Transplantation Using a Treosulfan-based Myeloablative Conditioning and Peripheral Blood Stem Cells. Biol. Blood Marrow Transplant. J. Am. Soc. Blood Marrow Transplant. 2015, 21, 1506-1514. [CrossRef] [PubMed]

9. $\quad$ Berger, M.; Lanino, E.; Cesaro, S.; Zecca, M.; Vassallo, E.; Faraci, M.; De Bortoli, M.; Barat, V.; Prete, A.; Fagioli, F. Feasibility and Outcome of Haploidentical Hematopoietic Stem Cell Transplantation with Post-Transplant High-Dose Cyclophosphamide for Children and Adolescents with Hematologic Malignancies: An AIEOP-GITMO Retrospective Multicenter Study. Biol. Blood Marrow Transplant. J. Am. Soc. Blood Marrow Transplant. 2016, 22, 902-909. [CrossRef]

10. Retière, C.; Willem, C.; Guillaume, T.; Vié, H.; Gautreau-Rolland, L.; Scotet, E.; Saulquin, X.; Gagne, K.; Béné, M.C.; Imbert, B.M.; et al. Impact on early outcomes and immune reconstitution of high-dose post-transplant cyclophosphamide vs anti-thymocyte globulin after reduced intensity conditioning peripheral blood stem cell allogeneic transplantation. Oncotarget 2018, 9, 11451-11464. [CrossRef] [PubMed]

11. Pasquini, M.C.; Devine, S.; Mendizabal, A.; Baden, L.R.; Wingard, J.R.; Lazarus, H.M.; Appelbaum, F.R.; Keever-Taylor, C.A.; Horowitz, M.M.; Carter, S.; et al. Comparative outcomes of donor graft CD34+ selection and immune suppressive therapy as graft-versus-host disease prophylaxis for patients with acute myeloid leukemia in complete remission undergoing HLA-matched sibling allogeneic hematopoietic cell transplantation. J. Clin. Oncol. Off. J. Am. Soc. Clin. Oncol. 2012, 30, $3194-3201$.

12. Barba, P.; Hilden, P.; Devlin, S.M.; Maloy, M.; Dierov, D.; Nieves, J.; Garrett, M.D.; Sogani, J.; Cho, C.; Barker, J.N.; et al. Ex Vivo CD34(+)-Selected T Cell-Depleted Peripheral Blood Stem Cell Grafts for Allogeneic Hematopoietic Stem Cell Transplantation in Acute Leukemia and Myelodysplastic Syndrome Is Associated with Low Incidence of Acute and Chronic Graft-versus-Host Disease and High Treatment Response. Biol. Blood Marrow Transplant. J. Am. Soc. Blood Marrow Transplant. 2017, 23, 452-458.

13. de Witte, M.A.; Janssen, A.; Nijssen, K.; Karaiskaki, F.; Swanenberg, L.; van Rhenen, A.; Admiraal, R.; van der Wagen, L.; Minnema, M.C.; Petersen, E.; et al. $\alpha \beta$ T-cell graft depletion for allogeneic HSCT in adults with hematological malignancies. Blood Adv. 2021, 5, 240-249. [CrossRef]

14. Laberko, A.; Sultanova, E.; Gutovskaya, E.; Shipitsina, I.; Shelikhova, L.; Kurnikova, E.; Muzalevskii, Y.; Kazachenok, A.; Pershin, D.; Voronin, K.; et al. Mismatched related vs matched unrelated donors in TCR $\alpha \beta / C D 19$-depleted HSCT for primary immunodeficiencies. Blood 2019, 134, 1755-1763. [CrossRef] [PubMed]

15. Maschan, M.; Shelikhova, L.; Ilushina, M.; Kurnikova, E.; Boyakova, E.; Balashov, D.; Persiantseva, M.; Skvortsova, Y.; Laberko, A.; Muzalevskii, Y.; et al. TCR-alpha/beta and CD19 depletion and treosulfan-based conditioning regimen in unrelated and haploidentical transplantation in children with acute myeloid leukemia. Bone Marrow Transplant. 2016, 51, 668-674. [CrossRef] [PubMed]

16. Bertaina, A.; Merli, P.; Rutella, S.; Pagliara, D.; Bernardo, M.E.; Masetti, R.; Pende, D.; Falco, M.; Handgretinger, R.; Moretta, F. HLA-haploidentical stem cell transplantation after removal of $\alpha \beta+\mathrm{T}$ and B cells in children with nonmalignant disorders. Blood 2014, 124, 822-826. [CrossRef]

17. Kierkels, G.J.J.; van Diest, E.; Hernández-López, P.; Scheper, W.; de Bruin, A.C.M.; Frijlink, E.; Aarts-Riemens, T.; van Dooremalen, S.F.J.; Beringer, D.X.; Oostvogels, R.; et al. Characterization and modulation of anti- $\alpha \beta T C R$ antibodies and their respective binding sites at the $\beta$ TCR chain to enrich engineered T cells. Mol. Ther. Methods Clin. Dev. 2021, 22, 388-400. [CrossRef] [PubMed]

18. Annaloro, C.; Serpenti, F.; Saporiti, G.; Galassi, G.; Cavallaro, F.; Grifoni, F.; Goldaniga, M.; Baldini, L.; Onida, F. Viral Infections in HSCT: Detection, Monitoring, Clinical Management, and Immunologic Implications. Front. Immunol. 2020, 11, 569381. [CrossRef]

19. Hill, J.A.; Mayer, B.T.; Xie, H.; Leisenring, W.M.; Huang, M.L.; Stevens-Ayers, T.; Milano, F.; Delaney, C.; Sorror, M.L.; Sandmaier B.M.; et al. The cumulative burden of double-stranded DNA virus detection after allogeneic HCT is associated with increased mortality. Blood 2017, 129, 2316-2325. [CrossRef] [PubMed]

20. Rustia, E.; Violago, L.; Jin, Z.; Foca, M.D.; Kahn, J.M.; Arnold, S.; Sosna, J.; Bhatia, M.; Kung, A.L.; George, D.; et al. Risk Factors and Utility of a Risk-Based Algorithm for Monitoring Cytomegalovirus, Epstein-Barr Virus, and Adenovirus Infections in Pediatric Recipients after Allogeneic Hematopoietic Cell Transplantation. Biol. Blood Marrow Transplant. J. Am. Soc. Blood Marrow Transplant. 2016, 22, 1646-1653. [CrossRef]

21. Admiraal, R.; de Koning, C.C.H.; Lindemans, C.A.; Bierings, M.B.; Wensing, A.M.J.; Versluys, A.B.; Wolfs, T.F.W.; Nierkens, S.; Boelens, J.J. Viral reactivations and associated outcomes in the context of immune reconstitution after pediatric hematopoietic cell transplantation. J. Allergy Clin. Immunol. 2017, 140, 1643-1650.e9. [CrossRef] [PubMed]

22. Illiaquer, M.; Imbert-Marcille, B.M.; Guillaume, T.; Planche, L.; Rimbert, M.; Bressollette-Bodin, C.; Le Bourgeois, A.; Peterlin, P.; Garnier, A.; Le Houerou, C.; et al. Impact of stem cell graft on early viral infections and immune reconstitution after allogeneic transplantation in adults. J. Clin. Virol. 2017, 93, 30-36. [CrossRef] [PubMed] 
23. Langenhorst, J.B.; Boss, J.; van Kesteren, C.; Lalmohamed, A.; Kuball, J.; Egberts, A.C.G.; Boelens, J.J.; Huitema, A.D.R.; van Maarseveen, E.M. A semi-mechanistic model based on glutathione depletion to describe intra-individual reduction in busulfan clearance. Br. J. Clin. Pharm. 2020, 86, 1499-1509. [CrossRef]

24. Bartelink, I.H.; Lalmohamed, A.; van Reij, E.M.; Dvorak, C.C.; Savic, R.M.; Zwaveling, J.; Bredius, R.G.; Egberts, A.C.; Bierings, M.; Kletzel, M.; et al. Association of busulfan exposure with survival and toxicity after haemopoietic cell transplantation in children and young adults: A multicentre, retrospective cohort analysis. Lancet Haematol. 2016, 3, e526-e536. [CrossRef]

25. Admiraal, R.; Lindemans, C.A.; van Kesteren, C.; Bierings, M.B.; Versluijs, A.B.; Nierkens, S.; Boelens, J.J. Excellent T-cell reconstitution and survival depend on low ATG exposure after pediatric cord blood transplantation. Blood 2016, 128, $2734-2741$. [CrossRef] [PubMed]

26. Admiraal, R.; van Kesteren, C.; Jol-van der Zijde, C.M.; Lankester, A.C.; Bierings, M.B.; Egberts, T.C.; van Tol, M.J.; Knibbe, C.A.; Bredius, R.G.; Boelens, J.J. Association between anti-thymocyte globulin exposure and CD4+ immune reconstitution in paediatric haemopoietic cell transplantation: A multicentre, retrospective pharmacodynamic cohort analysis. Lancet Haematol. 2015, 2, e194-e203. [CrossRef]

27. de Koning, C.; Prockop, S.; van Roessel, I.; Kernan, N.; Klein, E.; Langenhorst, J.; Szanto, C.; Belderbos, M.; Bierings, M.; Boulad, F.; et al. CD4+ T-cell reconstitution predicts survival outcomes after acute graft-versus-host-disease: A dual-center validation. Blood 2021, 137, 848-855. [CrossRef]

28. van Roessel, I.; Prockop, S.; Klein, E.; Boulad, F.; Scaradavou, A.; Spitzer, B.; Kung, A.; Curran, K.; O’Reilly, R.J.; Kernan, N.A.; et al. Early CD4+ T cell reconstitution as predictor of outcomes after allogeneic hematopoietic cell transplantation. Cytotherapy 2020, 22, 503-510. [CrossRef]

29. de Koning, C.; Langenhorst, J.; van Kesteren, C.; Lindemans, C.A.; Huitema, A.D.R.; Nierkens, S.; Boelens, J.J. Innate Immune Recovery Predicts CD4(+) T Cell Reconstitution after Hematopoietic Cell Transplantation. Biol. Blood Marrow Transplant. J. Am. Soc. Blood Marrow Transplant. 2019, 25, 819-826. [CrossRef]

30. de Koning, C.; Admiraal, R.; Nierkens, S.; Boelens, J.J. Human herpesvirus 6 viremia affects T-cell reconstitution after allogeneic hematopoietic stem cell transplantation. Blood Adv. 2018, 2, 428-432. [CrossRef]

31. Schmid, C.; Kuball, J.; Bug, G. Defining the Role of Donor Lymphocyte Infusion in High-Risk Hematologic Malignancies. J. Clin. Oncol. Off. J. Am. Soc. Clin. Oncol. 2021, 39, 397-418. [CrossRef] [PubMed]

32. Frederik Falkenburg, J.H.; Schmid, C.; Kolb, H.J.; Locatelli, F.; Kuball, J. Delayed Transfer of Immune Cells or the Art of Donor Lymphocyte Infusion. In The EBMT Handbook: Hematopoietic Stem Cell Transplantation and Cellular Therapies; Carreras, E., Dufour, C., Mohty, M., Kröger, N., Eds.; Springer: Cham, Switzerland, 2019; pp. 443-448.

33. Kuball, J.; Boelens, J.J. Clinical and Biological Concepts for Mastering Immune Reconstitution After HSCT: Toward Practical Guidelines and Greater Harmonization. In The EBMT Handbook: Hematopoietic Stem Cell Transplantation and Cellular Therapies; Carreras, E., Dufour, C., Mohty, M., Kröger, N., Eds.; Springer: Cham, Switzerland, 2019; pp. 69-74.

34. Locatelli, F.; Merli, P.; Pagliara, D.; Li Pira, G.; Falco, M.; Pende, D.; Rondelli, R.; Lucarelli, B.; Brescia, L.P.; Masetti, R.; et al. Outcome of children with acute leukemia given HLA-haploidentical HSCT after $\alpha \beta$ T-cell and B-cell depletion. Blood 2017, 130, 677-685. [CrossRef]

35. Admiraal, R.; Nierkens, S.; de Witte, M.A.; Petersen, E.J.; Fleurke, G.J.; Verrest, L.; Belitser, S.V.; Bredius, R.G.M.; Raymakers, R.A.P.; Knibbe, C.A.J.; et al. Association between anti-thymocyte globulin exposure and survival outcomes in adult unrelated haemopoietic cell transplantation: A multicentre, retrospective, pharmacodynamic cohort analysis. Lancet Haematol. 2017, 4 , e183-e191. [CrossRef]

36. Boelens, J.J.; Admiraal, R.; Kuball, J.; Nierkens, S. Fine-Tuning Antithymocyte Globulin Dosing and Harmonizing Clinical Trial Design. J. Clin. Oncol. Off. J. Am. Soc. Clin. Oncol. 2018, 36, 1175-1176. [CrossRef] [PubMed]

37. Storek, J. Immunological reconstitution after hematopoietic cell transplantation-Its relation to the contents of the graft. Expert Opin. Biol. Ther. 2008, 8, 583-597. [CrossRef]

38. Dunbar, A.; Schauwvlieghe, A.; Algoe, S.; van Hellemond, J.J.; Reynders, M.; Vandecasteele, S.; Boelens, J.; Depuydt, P.; Rijnders, B. Epidemiology of Pneumocystis jirovecii Pneumonia and (Non-)use of Prophylaxis. Front. Cell Infect. Microbiol. 2020, 10, 224. [CrossRef] [PubMed]

39. Hirokawa, M.; Horiuchi, T.; Kawabata, Y.; Kitabayashi, A.; Miura, A.B. Reconstitution of gammadelta T cell repertoire diversity after human allogeneic hematopoietic cell transplantation and the role of peripheral expansion of mature $\mathrm{T}$ cell population in the graft. Bone Marrow Transplant. 2000, 26, 177-185. [CrossRef] [PubMed]

40. Ravens, S.; Schultze-Florey, C.; Raha, S.; Sandrock, I.; Drenker, M.; Oberdorfer, L.; Reinhardt, A.; Ravens, I.; Beck, M.; Geffers, R.; et al. Human gammadelta $\mathrm{T}$ cells are quickly reconstituted after stem-cell transplantation and show adaptive clonal expansion in response to viral infection. Nat. Immunol. 2017, 18, 393-401. [CrossRef]

41. Sebestyen, Z.; Prinz, I.; Dechanet-Merville, J.; Silva-Santos, B.; Kuball, J. Translating gammadelta (gammadelta) T cells and their receptors into cancer cell therapies. Nat. Rev. Drug Discov. 2020, 19, 169-184. [CrossRef]

42. Kabelitz, D.; Serrano, R.; Kouakanou, L.; Peters, C.; Kalyan, S. Cancer immunotherapy with gammadelta T cells: Many paths ahead of us. Cell Mol. Immunol. 2020, 17, 925-939. [CrossRef]

43. Caron, J.; Ridgley, L.A.; Bodman-Smith, M. How to Train Your Dragon: Harnessing Gamma Delta T Cells Antiviral Functions and Trained Immunity in a Pandemic Era. Front. Immunol. 2021, 12, 666983. [CrossRef] [PubMed] 
44. Wesch, D.; Peters, C.; Oberg, H.H.; Pietschmann, K.; Kabelitz, D. Modulation of $\gamma \delta$ T cell responses by TLR ligands. Cell Mol. Life Sci. 2011, 68, 2357-2370. [CrossRef]

45. Couzi, L.; Pitard, V.; Moreau, J.F.; Merville, P.; Déchanet-Merville, J. Direct and Indirect Effects of Cytomegalovirus-Induced $\gamma \delta \mathrm{T}$ Cells after Kidney Transplantation. Front. Immunol. 2015, 6, 3. [CrossRef]

46. Lamb, L.S., Jr.; Henslee-Downey, P.J.; Parrish, R.S.; Godder, K.; Thompson, J.; Lee, C.; Gee, A.P. Increased frequency of TCR gamma delta $+\mathrm{T}$ cells in disease-free survivors following $\mathrm{T}$ cell-depleted, partially mismatched, related donor bone marrow transplantation for leukemia. J. Hematother. 1996, 5, 503-509. [CrossRef]

47. Godder, K.T.; Henslee-Downey, P.J.; Mehta, J.; Park, B.S.; Chiang, K.Y.; Abhyankar, S.; Lamb, L.S. Long term disease-free survival in acute leukemia patients recovering with increased gammadelta $\mathrm{T}$ cells after partially mismatched related donor bone marrow transplantation. Bone Marrow Transplant. 2007, 39, 751-757. [CrossRef]

48. Perko, R.; Kang, G.; Sunkara, A.; Leung, W.; Thomas, P.G.; Dallas, M.H. Gamma delta T cell reconstitution is associated with fewer infections and improved event-free survival after hematopoietic stem cell transplantation for pediatric leukemia. Biol. Blood Marrow Transplant. J. Am. Soc. Blood Marrow Transplant. 2015, 21, 130-136. [CrossRef]

49. Minculescu, L.; Marquart, H.V.; Ryder, L.P.; Andersen, N.S.; Schjoedt, I.; Friis, L.S.; Kornblit, B.T.; Petersen, S.L.; Haastrup, E.; Fischer-Nielsen, A.; et al. Improved Overall Survival, Relapse-Free-Survival, and Less Graft-vs.-Host-Disease in Patients With High Immune Reconstitution of TCR Gamma Delta Cells 2 Months After Allogeneic Stem Cell Transplantation. Front. Immunol. 2019, 10, 1997. [CrossRef] [PubMed]

50. Gaballa, A.; Stikvoort, A.; Önfelt, B.; Mattsson, J.; Sundin, M.; Watz, E.; Uhlin, M. T-cell frequencies of CD8(+) $\gamma \delta$ and CD27(+) $\gamma \delta$ cells in the stem cell graft predict the outcome after allogeneic hematopoietic cell transplantation. Bone Marrow Transplant. 2019, 54, 1562-1574. [CrossRef]

51. Arruda, L.C.M.; Gaballa, A.; Uhlin, M. Impact of $\gamma \delta \mathrm{T}$ cells on clinical outcome of hematopoietic stem cell transplantation: Systematic review and meta-analysis. Blood Adv. 2019, 3, 3436-3448. [CrossRef] [PubMed]

52. Vantourout, P.; Hayday, A. Six-of-the-best: Unique contributions of gammadelta T cells to immunology. Nat. Rev. Immunol. 2013, 13, 88-100. [CrossRef]

53. Cano, C.E.; Pasero, C.; De Gassart, A.; Kerneur, C.; Gabriac, M.; Fullana, M.; Granarolo, E.; Hoet, R.; Scotet, E.; Rafia, C.; et al. BTN2A1, an immune checkpoint targeting V $\gamma 9$ V $\delta 2$ T cell cytotoxicity against malignant cells. Cell Rep. 2021, 36, 109359. [CrossRef] [PubMed]

54. Rigau, M.; Ostrouska, S.; Fulford, T.S.; Johnson, D.N.; Woods, K.; Ruan, Z.; McWilliam, H.E.G.; Hudson, C.; Tutuka, C.; Wheatley, A.K.; et al. Butyrophilin 2A1 is essential for phosphoantigen reactivity by $\gamma \delta$ T cells. Science 2020, 367, 6478. [CrossRef] [PubMed]

55. Vyborova, A.; Beringer, D.X.; Fasci, D.; Karaiskaki, F.; van Diest, E.; Kramer, L.; de Haas, A.; Sanders, J.; Janssen, A.; Straetemans, T.; et al. $\gamma 9 \delta 2 \mathrm{~T}$ cell diversity and the receptor interface with tumor cells. J. Clin. Investig. 2020, 130, 4637-4651. [CrossRef] [PubMed]

56. Willcox, C.R.; Vantourout, P.; Salim, M.; Zlatareva, I.; Melandri, D.; Zanardo, L.; George, R.; Kjaer, S.; Jeeves, M.; Mohammed, F.; et al. Butyrophilin-like 3 Directly Binds a Human V $\gamma 4(+)$ T Cell Receptor Using a Modality Distinct from Clonally-Restricted Antigen. Immunity 2019, 51, 813-825.e4. [CrossRef]

57. Starick, L.; Riano, F.; Karunakaran, M.M.; Kunzmann, V.; Li, J.; Kreiss, M.; Amslinger, S.; Scotet, E.; Olive, D.; De Libero, G.; et al Butyrophilin 3A (BTN3A, CD277)-specific antibody 20.1 differentially activates V $\gamma 9 \mathrm{~V} \delta 2$ TCR clonotypes and interferes with phosphoantigen activation. Eur. J. Immunol. 2017, 47, 982-992. [CrossRef]

58. Sebestyen, Z.; Scheper, W.; Vyborova, A.; Gu, S.; Rychnavska, Z.; Schiffler, M.; Cleven, A.; Cheneau, C.; van Noorden, M.; Peigne, C.M.; et al. RhoB Mediates Phosphoantigen Recognition by Vgamma9Vdelta2 T Cell Receptor. Cell Rep. 2016, 15, 1973-1985. [CrossRef]

59. Harly, C.; Peigné, C.M.; Scotet, E. Molecules and Mechanisms Implicated in the Peculiar Antigenic Activation Process of Human V $\gamma 9$ V 82 T Cells. Front. Immunol. 2014, 5, 657. [PubMed]

60. Janssen, A.; Villacorta Hidalgo, J.; Beringer, D.X.; van Dooremalen, S.; Fernando, F.; van Diest, E.; Terrizi, A.R.; Bronsert, P.; Kock, S.; Schmitt-Graff, A.; et al. gammadelta T-cell Receptors Derived from Breast Cancer-Infiltrating T Lymphocytes Mediate Antitumor Reactivity. Cancer Immunol. Res. 2020, 8, 530-543. [CrossRef]

61. Kierkels, G.J.J.; Scheper, W.; Meringa, A.D.; Johanna, I.; Beringer, D.X.; Janssen, A.; Schiffler, M.; Aarts-Riemens, T.; Kramer, L.; Straetemans, T.; et al. Identification of a tumor-specific allo-HLA-restricted $\gamma \delta$ TCR. Blood Adv. 2019, 3, 2870-2882. [CrossRef]

62. Johanna, I.; Hernández-López, P.; Heijhuurs, S.; Bongiovanni, L.; de Bruin, A.; Beringer, D.; van Dooremalen, S.; Shultz, L.D.; Ishikawa, F.; Sebestyen, Z.; et al. TEG011 persistence averts extramedullary tumor growth without exerting off-target toxicity against healthy tissues in a humanized HLA-A*24:02 transgenic mice. J. Leukoc. Biol. 2020, 107, 1069-1079. [CrossRef]

63. Johanna, I.; Straetemans, T.; Heijhuurs, S.; Aarts-Riemens, T.; Norell, H.; Bongiovanni, L.; de Bruin, A.; Sebestyen, Z.; Kuball, J. Evaluating in vivo efficacy-Toxicity profile of TEG001 in humanized mice xenografts against primary human AML disease and healthy hematopoietic cells. J. Immunother. Cancer 2019, 7, 69. [CrossRef]

64. Johanna, I.; Hernández-López, P.; Heijhuurs, S.; Scheper, W.; Bongiovanni, L.; de Bruin, A.; Beringer, D.X.; Oostvogels, R.; Straetemans, T.; Sebestyen, Z.; et al. Adding Help to an HLA-A*24:02 Tumor-Reactive $\gamma \delta$ TCR Increases Tumor Control. Front. Immunol. 2021, 12, 4436. [CrossRef] 
65. Ciccone, E.; Viale, O.; Pende, D.; Malnati, M.; Battista Ferrara, G.; Barocci, S.; Moretta, A.; Moretta, L. Specificity of human $\mathrm{T}$ lymphocytes expressing a gamma/delta T cell antigen receptor. Recognition of a polymorphic determinant of HLA class I molecules by a gamma/delta clone. Eur. J. Immunol. 1989, 19, 1267-1271. [CrossRef] [PubMed]

66. Spits, H.; Paliard, X.; Engelhard, V.H.; de Vries, J.E. Cytotoxic activity and lymphokine production of T cell receptor (TCR)-alpha beta+ and TCR-gamma delta+ cytotoxic T lymphocyte (CTL) clones recognizing HLA-A2 and HLA-A2 mutants. Recognition of TCR-gamma delta+ CTL clones is affected by mutations at positions 152 and 156. J. Immunol. 1990, 144, 4156-4162. [PubMed]

67. Del Porto, P.; D'Amato, M.; Fiorillo, M.T.; Tuosto, L.; Piccolella, E.; Sorrentino, R. Identification of a novel HLA-B27 subtype by restriction analysis of a cytotoxic gamma delta T cell clone. J. Immunol. 1994, 153, 3093-3100.

68. Fujishima, N.; Hirokawa, M.; Fujishima, M.; Yamashita, J.; Saitoh, H.; Ichikawa, Y.; Horiuchi, T.; Kawabata, Y.; Sawada, K.I. Skewed T cell receptor repertoire of Vdelta1(+) gammadelta $\mathrm{T}$ lymphocytes after human allogeneic haematopoietic stem cell transplantation and the potential role for Epstein-Barr virus-infected B cells in clonal restriction. Clin. Exp. Immunol. 2007, 149, 70-79. [CrossRef]

69. Knight, A.; Madrigal, A.J.; Grace, S.; Sivakumaran, J.; Kottaridis, P.; Mackinnon, S.; Travers, P.J.; Lowdell, M.W. The role of Vdelta2-negative gammadelta $\mathrm{T}$ cells during cytomegalovirus reactivation in recipients of allogeneic stem cell transplantation. Blood 2010, 116, 2164-2172. [CrossRef] [PubMed]

70. Khairallah, C.; Dechanet-Merville, J.; Capone, M. gammadelta T Cell-Mediated Immunity to Cytomegalovirus Infection. Front. Immunol. 2017, 8, 105. [CrossRef]

71. de Witte, M.A.; Sarhan, D.; Davis, Z.; Felices, M.; Vallera, D.A.; Hinderlie, P.; Curtsinger, J.; Cooley, S.; Wagner, J.; Kuball, J.; et al. Early Reconstitution of NK and gammadelta T Cells and Its Implication for the Design of Post-Transplant Immunotherapy. Biol. Blood Marrow Transplant. J. Am. Soc. Blood Marrow Transplant. 2018. [CrossRef] [PubMed]

72. Airoldi, I.; Bertaina, A.; Prigione, I.; Zorzoli, A.; Pagliara, D.; Cocco, C.; Meazza, R.; Loiacono, F.; Lucarelli, B.; Bernardo, M.E.; et al. gammadelta T-cell reconstitution after HLA-haploidentical hematopoietic transplantation depleted of TCR-alphabeta+/CD19+ lymphocytes. Blood 2015, 125, 2349-2358. [CrossRef]

73. Bertaina, A.; Zorzoli, A.; Petretto, A.; Barbarito, G.; Inglese, E.; Merli, P.; Lavarello, C.; Brescia, L.P.; De Angelis, B.; Tripodi, G.; et al. Zoledronic acid boosts gammadelta T-cell activity in children receiving alphabeta(+) T and CD19(+) cell-depleted grafts from an HLA-haplo-identical donor. Oncoimmunology 2017, 6, e1216291. [CrossRef]

74. Scheper, W.; van Dorp, S.; Kersting, S.; Pietersma, F.; Lindemans, C.; Hol, S.; Heijhuurs, S.; Sebestyen, Z.; Grunder, C.; MarcuMalina, V.; et al. gammadeltaT cells elicited by CMV reactivation after allo-SCT cross-recognize CMV and leukemia. Leukemia 2013, 27, 1328-1338. [CrossRef]

75. Arruda, L.C.M.; Gaballa, A.; Uhlin, M. Graft gammadelta TCR Sequencing Identifies Public Clonotypes Associated with Hematopoietic Stem Cell Transplantation Efficacy in Acute Myeloid Leukemia Patients and Unravels Cytomegalovirus Impact on Repertoire Distribution. J. Immunol. 2019, 202, 1859-1870. [CrossRef]

76. Prinz, I.; Thamm, K.; Port, M.; Weissinger, E.M.; Stadler, M.; Gabaev, I.; Jacobs, R.; Ganser, A.; Koenecke, C. Donor V $\delta 1+\gamma \delta \mathrm{T}$ cells expand after allogeneic hematopoietic stem cell transplantation and show reactivity against CMV-infected cells but not against progressing B-CLL. Exp. Hematol. Oncol. 2013, 2, 14. [CrossRef]

77. Scheper, W.; Sebestyen, Z.; Kuball, J. Cancer Immunotherapy Using gammadeltaT Cells: Dealing with Diversity. Front. Immunol. 2014, 5, 601. [CrossRef] [PubMed]

78. Scheper, W.; Gründer, C.; Kuball, J. Multifunctional $\gamma \delta \mathrm{T}$ cells and their receptors for targeted anticancer immunotherapy. Oncoimmunology 2013, 2, e23974. [CrossRef]

79. Elmaagacli, A.H.; Steckel, N.K.; Koldehoff, M.; Hegerfeldt, Y.; Trenschel, R.; Ditschkowski, M.; Christoph, S.; Gromke, T.; Kordelas, L.; Ottinger, H.D.; et al. Early human cytomegalovirus replication after transplantation is associated with a decreased relapse risk: Evidence for a putative virus-versus-leukemia effect in acute myeloid leukemia patients. Blood 2011, 118, 1402-1412. [CrossRef]

80. Green, M.L.; Leisenring, W.M.; Xie, H.; Walter, R.B.; Mielcarek, M.; Sandmaier, B.M.; Riddell, S.R.; Boeckh, M. CMV reactivation after allogeneic HCT and relapse risk: Evidence for early protection in acute myeloid leukemia. Blood 2013, 122, 1316-1324. [CrossRef] [PubMed]

81. Peric, Z.; Wilson, J.; Durakovic, N.; Ostojic, A.; Desnica, L.; Vranjes, V.R.; Marekovic, I.; Serventi-Seiwerth, R.; Vrhovac, R. Early human cytomegalovirus reactivation is associated with lower incidence of relapse of myeloproliferative disorders after allogeneic hematopoietic stem cell transplantation. Bone Marrow Transplant. 2018, 53, 1450-1456. [CrossRef] [PubMed]

82. Schmidt-Hieber, M.; Labopin, M.; Beelen, D.; Volin, L.; Ehninger, G.; Finke, J.; Socié, G.; Schwerdtfeger, R.; Kröger, N.; Ganser, A.; et al. CMV serostatus still has an important prognostic impact in de novo acute leukemia patients after allogeneic stem cell transplantation: A report from the Acute Leukemia Working Party of EBMT. Blood 2013, 122, 3359-3364. [CrossRef] [PubMed]

83. Broers, A.E.; van Der Holt, R.; van Esser, J.W.; Gratama, J.W.; Henzen-Logmans, S.; Kuenen-Boumeester, V.; Löwenberg, B.; Cornelissen, J.J. Increased transplant-related morbidity and mortality in CMV-seropositive patients despite highly effective prevention of CMV disease after allogeneic T-cell-depleted stem cell transplantation. Blood 2000, 95, 2240-2245. [CrossRef]

84. Teira, P.; Battiwalla, M.; Ramanathan, M.; Barrett, A.J.; Ahn, K.W.; Chen, M.; Green, J.S.; Saad, A.; Antin, J.H.; Savani, B.N.; et al. Early cytomegalovirus reactivation remains associated with increased transplant-related mortality in the current era: A CIBMTR analysis. Blood 2016, 127, 2427-2438. [CrossRef] [PubMed]

85. Litjens, N.H.R.; van der Wagen, L.; Kuball, J.; Kwekkeboom, J. Potential Beneficial Effects of Cytomegalovirus Infection after Transplantation. Front. Immunol. 2018, 9, 389. [CrossRef] [PubMed] 
86. Déchanet, J.; Merville, P.; Bergé, F.; Bone-Mane, G.; Taupin, J.L.; Michel, P.; Joly, P.; Bonneville, M.; Potaux, L.; Moreau, J.F. Major expansion of gammadelta T lymphocytes following cytomegalovirus infection in kidney allograft recipients. J. Infect. Dis. 1999, 179, 1-8. [CrossRef] [PubMed]

87. Dechanet, J.; Merville, P.; Lim, A.; Retiere, C.; Pitard, V.; Lafarge, X.; Michelson, S.; Meric, C.; Hallet, M.M.; Kourilsky, P.; et al. Implication of gammadelta T cells in the human immune response to cytomegalovirus. J. Clin. Investig. 1999, 103, 1437-1449. [CrossRef]

88. Pitard, V.; Roumanes, D.; Lafarge, X.; Couzi, L.; Garrigue, I.; Lafon, M.E.; Merville, P.; Moreau, J.F.; Dechanet-Merville, J. Long-term expansion of effector/memory Vdelta2-gammadelta T cells is a specific blood signature of CMV infection. Blood 2008, 112, 1317-1324. [CrossRef]

89. Kaminski, H.; Ménard, C.; El Hayani, B.; Adjibabi, A.N.; Marsères, G.; Courant, M.; Zouine, A.; Pitard, V.; Garrigue, I.; Burrel, S.; et al. Characterization of a Unique $\gamma \delta$ T-Cell Subset as a Specific Marker of Cytomegalovirus Infection Severity. J. Infect. Dis. 2021, 223, 655-666. [CrossRef]

90. Styczynski, J.; van der Velden, W.; Fox, C.P.; Engelhard, D.; de la Camara, R.; Cordonnier, C.; Ljungman, P. Management of Epstein-Barr Virus infections and post-transplant lymphoproliferative disorders in patients after allogeneic hematopoietic stem cell transplantation: Sixth European Conference on Infections in Leukemia (ECIL-6) guidelines. Haematologica 2016, 101, 803-811. [CrossRef] [PubMed]

91. Liu, J.; Bian, Z.; Wang, X.; Xu, L.P.; Fu, Q.; Wang, C.; Chang, Y.J.; Wang, Y.; Zhang, X.H.; Jiang, Z.; et al. Inverse correlation of Vdelta2(+) T-cell recovery with EBV reactivation after haematopoietic stem cell transplantation. Br. J. Haematol. 2018, 180, 276-285. [CrossRef]

92. Xiang, Z.; Liu, Y.; Zheng, J.; Liu, M.; Lv, A.; Gao, Y.; Hu, H.; Lam, K.T.; Chan, G.C.; Yang, Y.; et al. Targeted activation of human Vgamma9Vdelta2-T cells controls epstein-barr virus-induced B cell lymphoproliferative disease. Cancer Cell 2014, 26, 565-576. [CrossRef]

93. Djaoud, Z.; Guethlein, L.A.; Horowitz, A.; Azzi, T.; Nemat-Gorgani, N.; Olive, D.; Nadal, D.; Norman, P.J.; Munz, C.; Parham, P. Two alternate strategies for innate immunity to Epstein-Barr virus: One using NK cells and the other NK cells and gammadelta $\mathrm{T}$ cells. J. Exp. Med. 2017, 214, 1827-1841. [CrossRef]

94. De Paoli, P.; Gennari, D.; Martelli, P.; Cavarzerani, V.; Comoretto, R.; Santini, G. Gamma delta T cell receptor-bearing lymphocytes during Epstein-Barr virus infection. J. Infect. Dis. 1990, 161, 1013-1016. [CrossRef] [PubMed]

95. Farnault, L.; Gertner-Dardenne, J.; Gondois-Rey, F.; Michel, G.; Chambost, H.; Hirsch, I.; Olive, D. Clinical evidence implicating gamma-delta T cells in EBV control following cord blood transplantation. Bone Marrow Transplant. 2013, 48, 1478-1479. [CrossRef] [PubMed]

96. Barcy, S.; De Rosa, S.C.; Vieira, J.; Diem, K.; Ikoma, M.; Casper, C.; Corey, L. Gamma delta+ T cells involvement in viral immune control of chronic human herpesvirus 8 infection. J. Immunol. 2008, 180, 3417-3425. [CrossRef] [PubMed]

97. Bukowski, J.F.; Morita, C.T.; Brenner, M.B. Recognition and destruction of virus-infected cells by human gamma delta CTL. J. Immunol. 1994, 153, 5133-5140.

98. Verjans, G.M.; Roest, R.W.; van der Kooi, A.; van Dijk, G.; van der Meijden, W.I.; Osterhaus, A. Isopentenyl pyrophosphate-reactive Vgamma9Vdelta $2 \mathrm{~T}$ helper 1-like cells are the major gammadelta $\mathrm{T}$ cell subset recovered from lesions of patients with genital herpes. J. Infect. Dis. 2004, 190, 489-493. [CrossRef] [PubMed]

99. Juno, J.A.; Eriksson, E.M. $\gamma \delta$ T-cell responses during HIV infection and antiretroviral therapy. Clin. Transl. Immunol. 2019, 8, e01069. [CrossRef]

100. Carissimo, G.; Xu, W.; Kwok, I.; Abdad, M.Y.; Chan, Y.H.; Fong, S.W.; Puan, K.J.; Lee, C.Y.; Yeo, N.K.; Amrun, S.N.; et al. Whole blood immunophenotyping uncovers immature neutrophil-to-VD2 T-cell ratio as an early marker for severe COVID-19. Nat. Commun. 2020, 11, 5243. [CrossRef] [PubMed]

101. Laing, A.G.; Lorenc, A.; Del Molino Del Barrio, I.; Das, A.; Fish, M.; Monin, L.; Muñoz-Ruiz, M.; McKenzie, D.R.; Hayday, T.S.; Francos-Quijorna, I.; et al. A dynamic COVID-19 immune signature includes associations with poor prognosis. Nat. Med. 2020, 26, 1623-1635. [CrossRef]

102. Li, H.; Xiang, Z.; Feng, T.; Li, J.; Liu, Y.; Fan, Y.; Lu, Q.; Yin, Z.; Yu, M.; Shen, C.; et al. Human V $\gamma 9$ V $\delta 2-T$ cells efficiently kill influenza virus-infected lung alveolar epithelial cells. Cell. Mol. Immunol. 2013, 10, 159-164. [CrossRef]

103. Babbe, H.; Chester, N.; Leder, P.; Reizis, B. The Bloom's syndrome helicase is critical for development and function of the alphabeta T-cell lineage. Mol. Cell Biol. 2007, 27, 1947-1959. [CrossRef]

104. Cazzetta, V.; Bruni, E.; Terzoli, S.; Carenza, C.; Franzese, S.; Piazza, R.; Marzano, P.; Donadon, M.; Torzilli, G.; Cimino, M.; et al. NKG2A expression identifies a subset of human V82 T cells exerting the highest antitumor effector functions. Cell Rep. 2021, 37, 109871. [CrossRef]

105. Di Lorenzo, B.; Simões, A.E.; Caiado, F.; Tieppo, P.; Correia, D.V.; Carvalho, T.; da Silva, M.G.; Déchanet-Merville, J.; Schumacher, T.N.; Prinz, I.; et al. Broad Cytotoxic Targeting of Acute Myeloid Leukemia by Polyclonal Delta One T Cells. Cancer Immunol. Res. 2019, 7, 552-558. [CrossRef] [PubMed]

106. Almeida, A.R.; Correia, D.V.; Fernandes-Platzgummer, A.; da Silva, C.L.; da Silva, M.G.; Anjos, D.R.; Silva-Santos, B. Delta One T Cells for Immunotherapy of Chronic Lymphocytic Leukemia: Clinical-Grade Expansion/Differentiation and Preclinical Proof of Concept. Clin. Cancer Res. Off. J. Am. Assoc. Cancer Res. 2016, 22, 5795-5804. [CrossRef] [PubMed] 
107. Leen, A.M.; Bollard, C.M.; Mendizabal, A.M.; Shpall, E.J.; Szabolcs, P.; Antin, J.H.; Kapoor, N.; Pai, S.Y.; Rowley, S.D.; Kebriaei, P.; et al. Multicenter study of banked third-party virus-specific T cells to treat severe viral infections after hematopoietic stem cell transplantation. Blood 2013, 121, 5113-5123. [CrossRef]

108. van der Veken, L.T.; Hagedoorn, R.S.; van Loenen, M.M.; Willemze, R.; Falkenburg, J.H.; Heemskerk, M.H. Alphabeta T-cell receptor engineered gammadelta T cells mediate effective antileukemic reactivity. Cancer Res. 2006, 66, 3331-3337. [CrossRef] [PubMed]

109. Dorrie, J.; Krug, C.; Hofmann, C.; Muller, I.; Wellner, V.; Knippertz, I.; Schierer, S.; Thomas, S.; Zipperer, E.; Printz, D.; et al. Human adenovirus-specific gamma/delta and CD8+ T cells generated by T-cell receptor transfection to treat adenovirus infection after allogeneic stem cell transplantation. PLOS ONE 2014, 9, e109944. [CrossRef]

110. Capsomidis, A.; Benthall, G.; Van Acker, H.H.; Fisher, J.; Kramer, A.M.; Abeln, Z.; Majani, Y.; Gileadi, T.; Wallace, R.; Gustafsson, K.; et al. Chimeric Antigen Receptor-Engineered Human Gamma Delta T Cells: Enhanced Cytotoxicity with Retention of Cross Presentation. Mol. Ther. 2018, 26, 354-365. [CrossRef]

111. Braham, M.V.J.; Minnema, M.C.; Aarts, T.; Sebestyen, Z.; Straetemans, T.; Vyborova, A.; Kuball, J.; Öner, F.C.; Robin, C.; Alblas, J. Cellular immunotherapy on primary multiple myeloma expanded in a 3D bone marrow niche model. Oncoimmunology 2018, 7, e1434465. [CrossRef]

112. Straetemans, T.; Kierkels, G.J.J.; Doorn, R.; Jansen, K.; Heijhuurs, S.; Dos Santos, J.M.; van Muyden, A.D.D.; Vie, H.; Clemenceau, B.; Raymakers, R.; et al. GMP-Grade Manufacturing of T Cells Engineered to Express a Defined $\gamma \delta T C R$. Front. Immunol. 2018, 9, 1062. [CrossRef]

113. Grunder, C.; van, D.S.; Hol, S.; Drent, E.; Straetemans, T.; Heijhuurs, S.; Scholten, K.; Scheper, W.; Sebestyen, Z.; Martens, A.; et al. gamma9 and delta2CDR3 domains regulate functional avidity of T cells harboring gamma9delta2TCRs. Blood 2012, 120, 5153-5162. [CrossRef] [PubMed]

114. Marcu-Malina, V.; Heijhuurs, S.; van, B.M.; Hartkamp, L.; Strand, S.; Sebestyen, Z.; Scholten, K.; Martens, A.; Kuball, J. Redirecting alphabeta T cells against cancer cells by transfer of a broadly tumor-reactive gammadeltaT-cell receptor. Blood 2011, 118, 50-59. [CrossRef]

115. van Diest, E.; Hernández López, P.; Meringa, A.D.; Vyborova, A.; Karaiskaki, F.; Heijhuurs, S.; Gumathi Bormin, J.; van Dooremalen, S.; Nicolasen, M.J.T.; Gatti, L.; et al. Gamma delta TCR anti-CD3 bispecific molecules (GABs) as novel immunotherapeutic compounds. J. Immunother. Cancer 2021, 9, e003850. [CrossRef] [PubMed]

116. Marty, F.M.; Ljungman, P.; Chemaly, R.F.; Maertens, J.; Dadwal, S.S.; Duarte, R.F.; Haider, S.; Ullmann, A.J.; Katayama, Y.; Brown, J.; et al. Letermovir Prophylaxis for Cytomegalovirus in Hematopoietic-Cell Transplantation. N. Engl. J. Med. 2017, 377, 2433-2444. [CrossRef] [PubMed]

117. Gratwohl, A.; Sureda, A.; Baldomero, H.; Gratwohl, M.; Dreger, P.; Kröger, N.; Ljungman, P.; McGrath, E.; Mohty, M.; Nagler, A.; et al. Economics and Outcome After Hematopoietic Stem Cell Transplantation: A Retrospective Cohort Study. eBioMedicine 2015, 2, 2101-2109. [CrossRef]

118. Chabannon, C.; Kuball, J.; Bondanza, A.; Dazzi, F.; Pedrazzoli, P.; Toubert, A.; Ruggeri, A.; Fleischhauer, K.; Bonini, C. Hematopoietic stem cell transplantation in its 60s: A platform for cellular therapies. Sci. Transl. Med. 2018, 10. [CrossRef]

119. Chabannon, C.; Kuball, J.; McGrath, E.; Bader, P.; Dufour, C.; Lankester, A.; Basak, G.W.; Montoto, S.; Nagler, A.; Snowden, J.A.; et al. CAR-T cells: The narrow path between hope and bankruptcy? Bone Marrow Transplant. 2017, 52, 1588-1589. [CrossRef] [PubMed]

120. Traversari, C.; Marktel, S.; Magnani, Z.; Mangia, P.; Russo, V.; Ciceri, F.; Bonini, C.; Bordignon, C. The potential immunogenicity of the TK suicide gene does not prevent full clinical benefit associated with the use of TK-transduced donor lymphocytes in HSCT for hematologic malignancies. Blood 2007, 109, 4708-4715. [CrossRef] 